\title{
Prograding low-density turbidite systems and oil traps at the Lower Paleogene Chicontepec Foreland Basin, East-Central Mexico
}

\section{Sistemas turbidíticos de baja densidad progradacionales y trampas de aceite en la Cuenca de Antepaís de Chicontepec del Paleógeno Inferior, Centro-Oriente de México}

Aguayo-Camargo Joaquín Eduardo

Facultad de Ingeniería, División de Ciencias de la Tierra

Universidad Nacional Autónoma de México

Correo: aguayoje@unam.mx

https://orcid.org/000-0001-7139-0868

Santillán-Piña Noé

Facultad de Ingeniería, División de Ciencias de la Tierra

Universidad Nacional Autónoma de México

Correo: noesant@unam.mx

https://orcid.org/000-0002-8502-0785
Arellano-Gil Javier

Facultad de Ingeniería, División de Ciencias de la Tierra

Universidad Nacional Autónoma de México

Correo: arellano@unam.mx

https://orcid.org/000-0001-6844-7958

\begin{abstract}
The Lower Paleogene Chicontepec Foreland Basin at the southern region of the Tertiary Tampico-Misantla Basin at East-Central Mexico, resulting from the loading pressure of the uplifted and thrust-folded front of the Sierra Madre Oriental, on the passive, unfolded and thermally in subsidence Cretaceous basement, during the northeastward tectonic stresses from the Laramide Orogeny, against the Tuxpan Island eastern.

The foreland basin consists stratigraphically of complex low density turbidite systems, being their detached and non-channelized outer-fan lobe facies the most conspicuous, composite by disperse and discontinue sandy lenses with tight and highly cemented calcareous lithofacies, micro-fractured and with micro-vugs by dissolution. The hydrocarbons flowed vertically from the underlay Cretaceous and Upper Jurassic rocks through the NW-SE dextral transpressive strike-slip fault planes and fractures, then spread laterally toward the micro-fractured sandy lenses and within the unconformable erosive surfaces, bounding the depositional systems (systems tracts), at different levels of the Chicontepec stratigraphic column, in a hybrid petroleum system with low permeability unconventional reservoirs.
\end{abstract}

Keywords: Gulf of Mexico, tertiary basin, tectonics, stratigraphy, gravity flows, sedimentary facies, oil trapping.

\section{Resumen}

La Cuenca de Antepaís de Chicontepec del Paleógeno Inferior, en la región sur de la Cuenca Terciaria Tampico-Misantla del CentroOriente de México, es el resultado de la presión de la carga del frente de la Sierra Madre Oriental emergida, cabalgada y plegada, sobre el basamento pasivo no plegado y en subsidencia termal del Cretácico, durante los esfuerzos tectónicos de la Orogenia Laramide hacia el noreste, contra la Isla de Tuxpan al este. La cuenca de antepaís consiste estratigráficamente de sistemas turbidíticos complejos de baja densidad, siendo sus facies de lóbulos de abanico externo, aislados y no canalizados, los más conspicuos; compuestos por lentes arenosos dispersos y discontinuos, con litofacies calcáreas compactas y altamente cementadas, micro-fracturadas y micro-cavernosas por disolución. Los hidrocarburos fluyeron verticalmente de las rocas infrayacentes del Cretácico y del Jurásico Superior, a través de los planos de fallas y fracturas de los sistemas transpresivos dextrales NW-SE, dispersándose lateralmente hacia los lentes arenosos micro-fracturados y entre las superficies discordantes y erosionadas, que enmarcan a los sistemas depositacionales (systems tracts), a diferentes niveles de la columna estratigráfica de Chicontepec, en un sistema petrolero híbrido con reservorios no convencionales con baja permeabilidad.

Descriptores: Golfo de Mexico, cuencas terciarias, tectonica, estratigrafía, flujos de gravedad, facies sedimentarias, entrampamiento de hidrocarburos. 


\section{Previous work}

Due to the complex tectono-sedimentary evolution of the Chicontepec geological province and its importance as oil reservoir, numerous studies have been done, previously and after the discovering in 1926 of the Chicontepec Play; although its commercial production began in 1952, after the exploration of the middle Cretaceous Tamabra Formation in the Presidente Alemán oil field, at the southeastern side of the foreland basin.

Previous geological works involving tectonics, stratigraphy and sedimentary settings from the Chicontepec Basin, were referred by Nájera (1952), López (1979), and The Mexican Geological Service (2007). Such authors pointed out that, Cummins R.T. in the first decade of the past century, informally named "Chicontepec" to the outcropped beds at the type locality, $2.5 \mathrm{Km}$ west of the Chicontepec village at Veracruz State; and also that, Dumble E.T. (1918) formally coined such lithostratigraphic units as Chicontepec Formation.

Forthcoming papers, such as Benavides (1956) interpreted the overlay Upper Eocene Tantoyuca Formation to be the "molasse" facies as the end of the Laramide Orogeny, because it contains lithic fragments from the Chicontepec Formation. Other later works (e.g., Busch and Govela, 1978; Salazar, 1980; among other authors), distinguished three members in the Chicontepec Formation, based on their litho-stratigraphic position and microfossil content:

1) Lower Chicontepec (Middle Paleocene)

2) Middle Chicontepec (Upper Paleocene)

3) Upper Chicontepec (Lower Eocene)

which overlay conformable the shaley Lower Paleocene Velazco Basal Formation. Also Busch and Govela (1978) explained the deep-water paleocanyon from the erosion of the Paleocene, Cretaceous and Upper Jurassic beds. Bitter $(1983,1993)$ defined the basin geometry and tectonics, type of sediments, depositional environments and paleocurrents, by means of lithofacies and sole marks. Sutter (1984) interpreted the thrust front of the Sierra Madre Oriental, occurring since late Maastrichtian to Late Paleocene. Sessarego et al. (2007) interpreted the lithofacies and depositional environments from the northwest and southern outcrops of the basin, and from oil fields in the paleochannel. Cossey (2008) referred from outcrops the several sedimentary environments and the lithofacies of the basin. Alzaga et al. $(2008 \mathrm{a}, \mathrm{b})$ explained the tectono-sedimentary evolution of the basin with numerical models. Santillán (2009) and Santillán and Aguayo (2011), described the sedi- mentary facies and the environmental settings at the northwestern portion of the Paleogene basin. Araujo (2010) interpreted the diagenesis in core samples by means of SEM and dispersive energy X-ray at the north-central sectors of the basin. Aguayo et al. (2013) proposed a sedimentological model for the Early Eocene mini-basin (paleochannel) in subsurface. Arellano et al. (2013) explained a stratigraphic and structural model related to oil migration. Vasquez et al. (2014) constructed the stratigraphic framework with detail biostratigraphy analysis in subsurface, defining five sequence limits from the Lower Paleogene supported by 33 wells. Other recent works are focused to subsurface geological oil-exploration (e.g., Ávila et al., 2017), and also in unpublished confidential technical reports, mainly sourced from Petróleos Mexicanos (PEMEX), Instituto Mexicano del Petróleo (IMP), Comisión Nacional de Hidrocarburos $(\mathrm{CNH})$, and private Oil Companies.

\section{INTRODUCTION}

The morphotectonic Chicontepec Basin, exhibits a sequence of low density turbidite systems (systems tracts) with sandy calcareous lithofacies, bearing micro-fractures and micro-vugs by dissolution within the disperse and discontinue lenses of the highly cemented tight calcareous sandstones, which were deposited in non-leveed distributary channels, detached and nonchannelized outer-fan lobes and inter-lobe facies. These facies are more conspicuous in the Middle Megasequence from Middle-Upper Paleocene, as the most important unconventional oil reservoirs in a hybrid petroleum system with low permeability $(<0.01 \mathrm{Md})$ (Arellano et al., 2013).

The Chicontepec Foreland Basin still is searching and drilling for oil exploration and production; then the success for oil exploration and extraction, from its complex tectono-sedimentary systems, is based on the improvement of the geological interpretation, in time and space (Aguayo et al., 2006).

\section{LOCALITY}

The Paleogene Chicontepec Foreland Basin locates at the southern portion of the Tertiary Tampico Embayment or Tampico-Misantla Basin, in the sub-province of the plains and low hills, onshore East-Central Mexico, and in the Sierra Madre Oriental and Huasteca Karst sub-provinces. The foreland basin is bordered to the north by the southern margin of the Tamaulipas Peninsula and the Bejuco-La Laja paleochannel; to the south by the Teziutlan (Jalapa) metamorphic massif; western 
by the easternmost front of the Sierra Madre Oriental, and to the east by the western margin of the Tuxpan Platform (Tuxpan Island) (Figure 1).

The foreland basin embraces several geographic states: northern Veracruz, southern Tamaulipas, southeastern San Luis Potosí, northeastern Hidalgo and northern Puebla. Regionally, the Paleogene Chicontepec foreland basin is elongate in shape, its longer axis is about $250 \mathrm{~km}$ oriented northwest-southeast, and its average width is $60 \mathrm{Km}(80 \mathrm{Km}$ maximum $/ 40 \mathrm{Km}$ minimum $)$ covering and area of about $11300 \mathrm{Km}^{2}$. The Early Eocene mini-basin (paleochannel) in subsurface, also is oriented northwest-southeast with about $130 \mathrm{Km}$ long, with a maximum width to the north of about $40 \mathrm{Km}$, and its south-easternmost extension the paleocanyon, as an erosional, narrow, deep and stepped physiographic feature, with approximately $30 \mathrm{Km}$ in length and $15 \mathrm{Km}$ wide. The mini-basin (paleochannel) and the paleocanyon cover an area of about $3300 \mathrm{Km}^{2}$. The geographic coordinates (ATG) of the Chicontepec Foreland Basin are: $20^{\circ} 15^{\prime}$ and $21^{\circ} 15^{\prime}$ North latitude; $97^{\circ} 05^{\prime}$ and $98^{0} 10^{\prime}$ West longitude (Figure 2).

\section{Овjectives}

The purpose of this work is, to identify and interpret the most conspicuous sedimentary lithofacies and their depositional settings, from the complex turbidite sys-
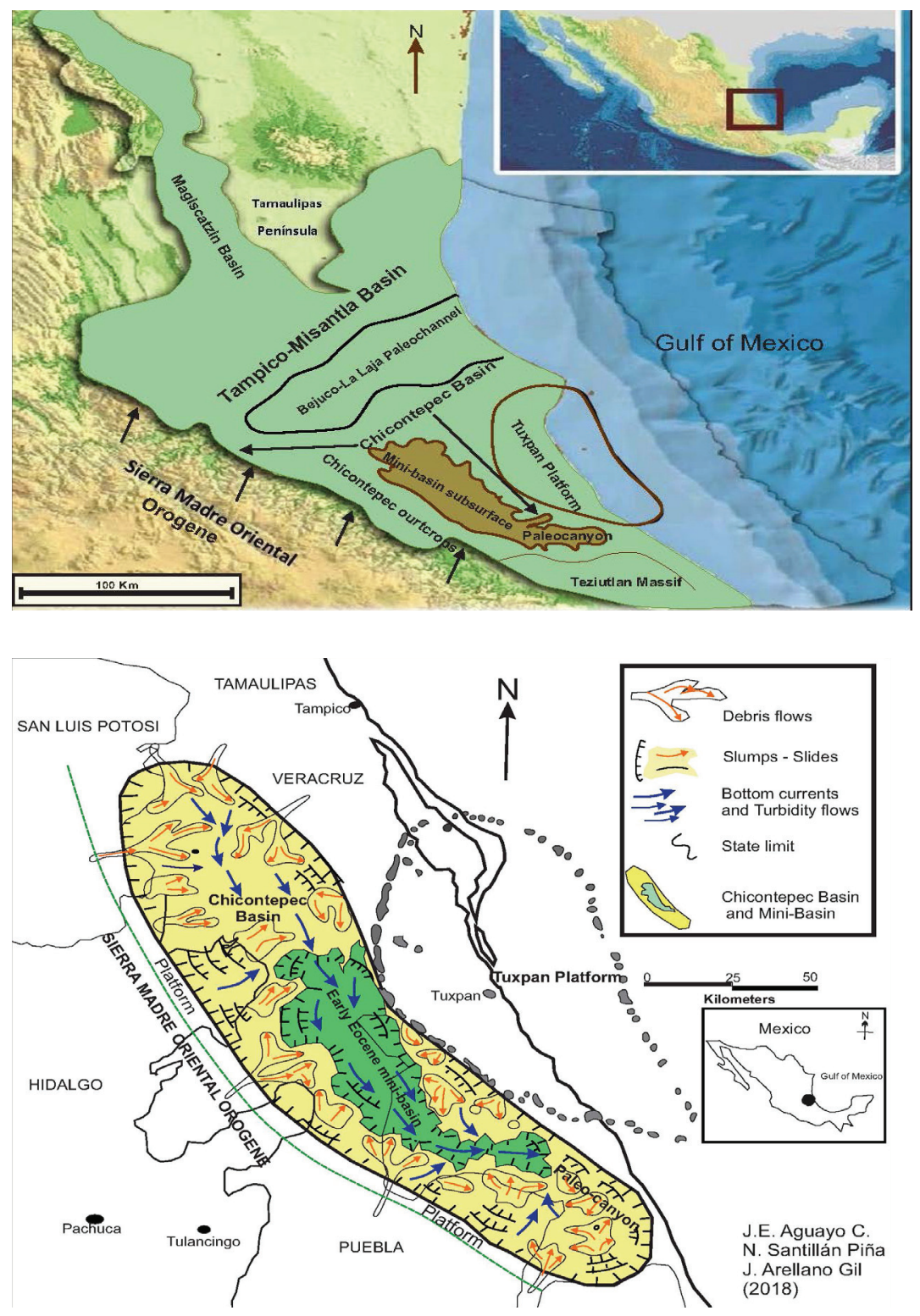

Figure1. The Chicontepec Basin at the Lower Paleogene tectonic framework of the Tampico-Misantla Basin, onshore Gulf of Mexico
Figure 2. Geographic and paleosedimentary settings of the Chicontepec Basin 
tems into the local and regional structural framework of the Lower Paleogene Chicontepec Foreland Basin; and to share geological data to predict low-risk areas as potential oil traps.

\section{Methods}

Based on the previous geological work, this study was enrichment with insights from more recent research held in outcrops and subsurface, for the authors of this work.

The stratigraphic columns were selected on the basis of road access and fresh outcrops in more than 30 sites. Field work consisted, to recognize the major geometric stratigraphic stacking and the type and distribution of the lithofacies (texture, mineralogy, and primary and secondary sedimentary structures). The sedimentary settings of the stratigraphic outcrops, were interpreted according to the "fan-model", proposed by Mutti and Ricci (1972; 1975), Mutti (1992), and Bouma (1962), for outer-fan classic turbidites. About 90 selected sandstone and siltstone rock samples were collected, and studied in thin sections under the petrographic and mineralogical binocular microscope Nikon, then integrated with the photographic camera Hitachi CCD model KP MIE. The data was processed by the software Enterprise Omnimet handle with Window's program.

The subsurface geological and geophysical information of the foreland basin, proceed from the research project carried-out in 2012 from the Universidad Nacional Autónoma de México (UNAM) and the Comisión Nacional de Hidrocarburos $(\mathrm{CNH})$, to determine the paleo-sedimentary sequences with geophysical logs from drilled wells in 8 oil fields from three sectors: the north, central and south sectors. The well geophysical information was supported by seismic sections, and also by petrographic analysis with standard thin sections from 18 selected core samples; 20 rock samples were processed with the Scanning Electron Microscope with dispersive energy X-ray at the Instituto Mexicano del Petróleo (IMP), to interpret the diagenetic paragenesis of the sedimentary lithofacies.

Nor micro-biostratigraphy study neither recognizing of ichnofacies were carried-out in this work, such information was taken on previous published papers and unpublished reports from PEMEX and IMP.

\section{Results AND Discussion}

\section{Sediment TYPE AND PROVENANCE}

The calcareous sediment resulting from the erosion of the eastern front of the Sierra Madre Oriental and from the western margin of Tuxpan Plataform (Tuxpan Island), as fine to medium-grained calcareous litharenites; the metamorphic sediments derived from the Teziutlan (Jalapa) massif at the south-easternmost border of the Chicontepec Basin; the volcanic ash particles are inferred to be sourced from the island arc complexes of the Sierra Madre Occidental, caused by the subduction of the Farallon oceanic plate, along the western margin of Mexico during the Laramide Orogeny.

The Chicontepec stratigraphic sequence is composed by texturally immature sedimentary rocks, with high cemented calcareous fragments as, tight and unsorted, subangular to sub-rounded, reworked particles from limy and cherty rocks, in a range of $50-70 \%$ from the total rock fragments (70 to $80 \%$ ). The calcareous particles derived from packstone and wackestone limestones bearing miliolids, globigerinids, red algae, mollusk shell fragments and scarce ooids and dolomite particles. Other rock fragments (10 to 20\%) and quartz grains derived from volcanic, metamorphic and plutonic igneous rocks; feldspars (plagioclase and less orthoclase and microcline) are locally abundant in fine-grained sandstones, siltstone rock fragments, and silty matrix. Other accessory minerals were recognized in fine-grained sandstone and silty matrix as: pyrite, apatite, biotite, muscovite and tourmaline. Into the inter-particle porosity several authigenetic minerals are present as: rombohedral calcite and Fe-calcite, euhedral quartz with overgrowths, and clay as: kaolinite, chlorite, smectite and sericite.

The sandy rock populations from the Chicontepec sequence, are displaying in Folk's ternary diagram (1974) (Figure 3) as: calcareous litharenites, feldsparcalcareous litharenites and even calclithites, when the calcareous percentage is more than $90 \%$, of sand-sized calcareous particles and calcite cement, which are more abundant in the north and central sectors of the foreland basin and also in the outcrops nearby to Poza Rica town at Veracruz State, where the sandstone is composed by quartz-calclithite. The silty-clayey and very finegrained sand particles from the volcanic ash, are more abundant in the north sector of the basin, and the metamorphic, medium and fine-grained sediments are mainly present in the south sector of the basin. Furthermore, mineralogical composition from sandstones, siltstones and clays, and their provenance and distribution in outcrops and from subsurface, were previously reported by Bitter (1993), Santillan (2009), Santillán and Aguayo (2011), Ávalos (2013), Ávalos et al. (2017), among other authors. 


\section{FACIES TYPE AND ASSOCIATION}

A turbidite fan system is a stratigraphic unit, which records a series of linked erosional and depositional elements. The system is bounded by a relative sharp or erosional basal surface, and the upper bounding surface can be sharp or transitional. The gravity flow systems were better understood only through the facies interpretation and their association, within the lateral and vertical stratigraphic relationships. The lateral facies association, record transformations that took place within the same flow along the different locations (systems-facies or systems-tracts); and the vertical stacking record transformations took place within the same flow at the same location. Both sedimentary sequences distinguished from their geometry and facies type, as products from the tectonic setting, relative sea level variations, and frequency and volume of gravity flows.

The texturally immature calcareous particles in the foreland basin, resulting from the erosion of the thrusted front from the Sierra Madre Oriental Orogene; the clastic particles were carried away initially by the inferred shallow marine coastal currents toward the border of a narrow shelf, then transported to the steep slope toward the deep foreland basin eastern, through an inferred feeder canyon near to Tanlajas Village at the northwestern border of the basin (Bitter, 1983; Cossey, 2008); and then, the turbidity currents flowed to the southeast along the sea bottom of the long axial depocenter of the foreland basin, parallel to the easternmost toe-thrusting front of the Sierra Madre Oriental Orogene (Figure 4).
The stratigraphic outcrops from the northwestern and southern border of the Chicontepec Basin, mainly consist of outer-fan lobe systems, with thick and laterally extensive sandstones of non-channelized and detached from the feeder channels; these gravity flows were large enough to extent laterally and spread-across the entire basin, onlapping on basin margins.

A possible explanation for the only presence of the outer-fan lobe facies at the northwestern side of the foreland basin, is because the feeder-channel and the inner- and mid-fan systems were overlapped or even exhumed, and partially or totally destroyed, during the toe-thrusting tectonic front events of the Sierra Madre Oriental, as it was interpreted by Bitter (1983) and Cossey (2008), and in accordance to the northwest uplifting of the passive-unfolded Cretaceous basement, and the tilting and subsidence to the southeast of the bottombase of the foreland basin (Figure 4).

The outer-fan lobes represent the maximum downcurrent extent of sand transported to the basin, with thickening-and coarsening-upward bedding, particularly as tabular bodies with individual thicknesses, between 3-15 $\mathrm{m}$ of medium to thick-bedded sandstones and thinner-bedding of finer-grained sandstones, alternating with silty-shale facies with incomplete Bouma's sequence, in which the $\mathrm{Ta}$ facies is commonly absent by erosion or not deposition. The facies Tb-e, Tc-e, Td-e and $\mathrm{Te}$, constitute the volumetrically most important sedimentary facies in the stratigraphic stack of the outer-fan lobe systems:

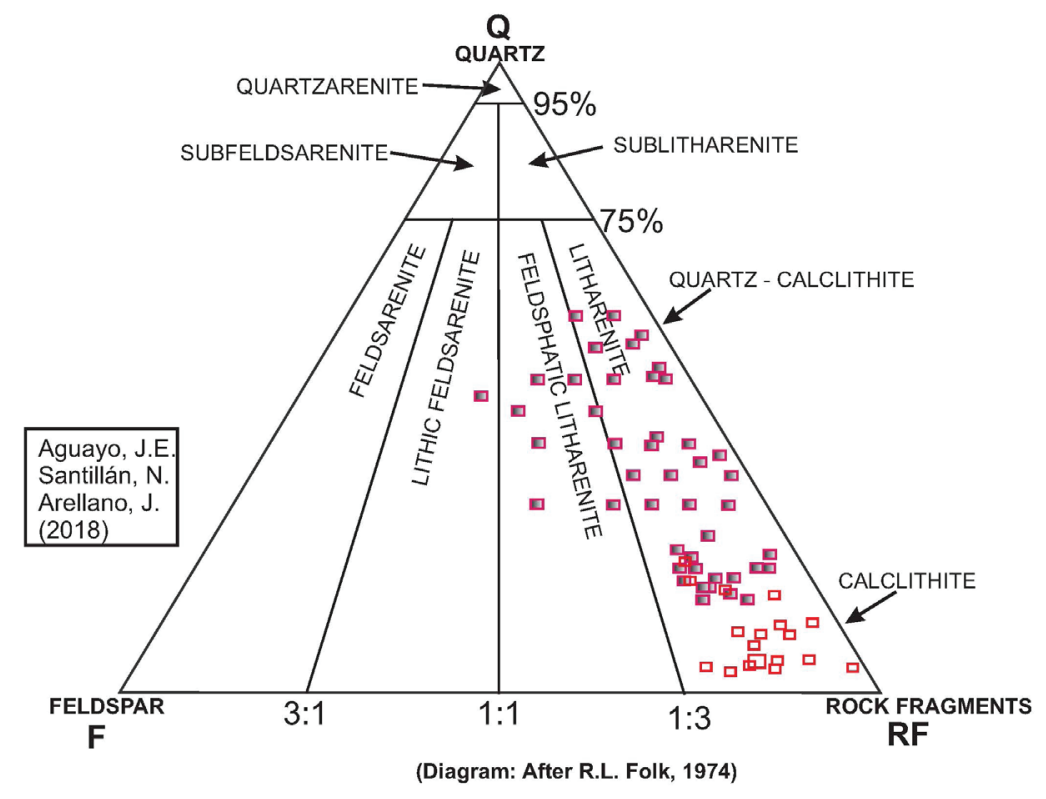

Figure 3. QFRF ternary diagram of sandstone populations from the Chicontepec Basin 


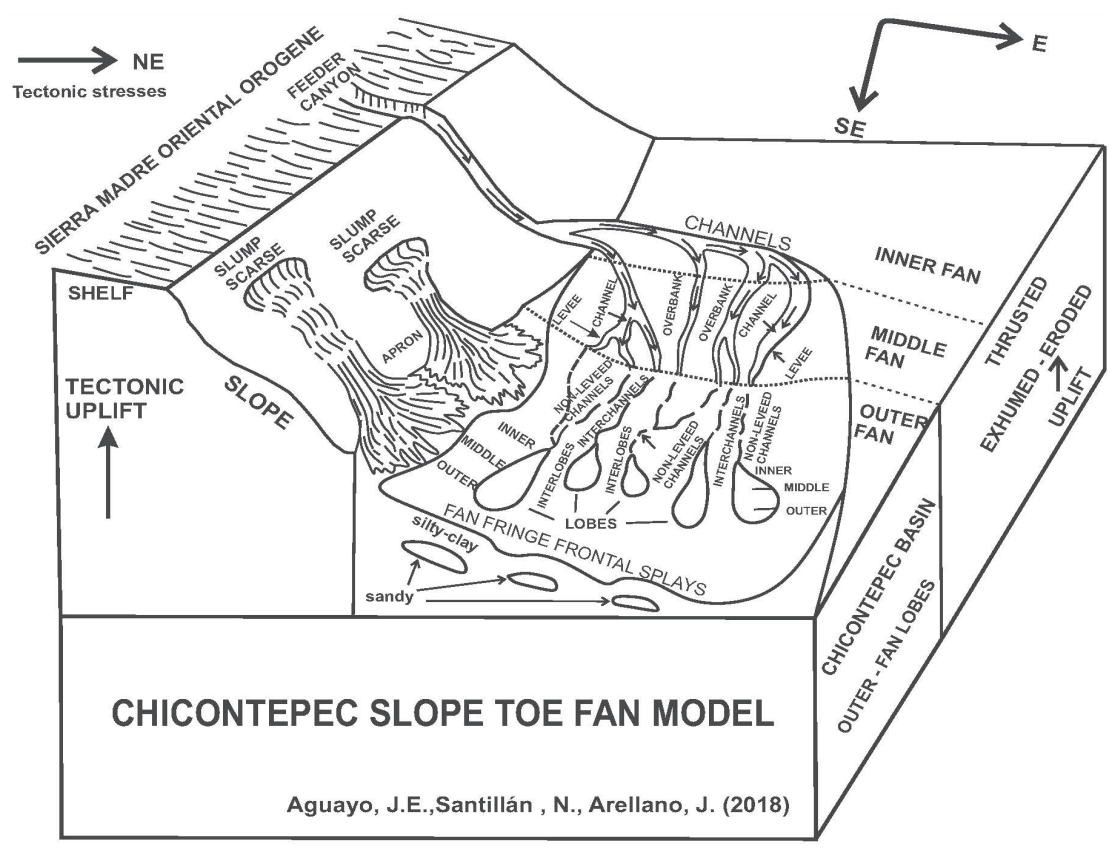

Figure 4. Conceptual model sketch from the slope toe-fan on the western margin of the Chicontepec Basin
1. Inner-lobe facies ( $T a-e$ and $T b-e$ ): thick and medium bedded of amalgamated, coarse to medium-grained sandstones and silty-clays.

2. Mid-lobe facies (Tb-e): medium bedded, medium to fine-grained sandstones and silty-clays.

3. Outer lobe facies (Td-e): thin-bedded and layers, fine to very fine-grained sandstones and silty clays.

4. Outer fan-fringe splayed facies (Te): thin layers of silty-clay. Other facies are locally interbedded within the formers.

5. Non-leveed channel-fill facies (Ta-c and Tb-c): massive and amalgamated, medium to fine-grained sandstones.

6. Cut-fill channels thinning-upward bearing conglomerate and coarse-grained sandstone facies.

7. Massive sloped muddy flow debris.

8. Massive transport conglomerates, feeder by canyons.

The outer-fan lobe facies frequently are associated with scoured sandstone bed bases with sole marks, such as: flute casts, grooves, prods and bounce casts, oriented to the southeast. Moreover, trace fossils from abundant ichnofacies are present, and were previously reported by Contreras and Argáez (1985), Bitter (2003), Cossey (2008), Santillán (2009), Santillán and Aguayo (2011), among others.

Each individual sedimentary deposit seems to be unique, in terms of lateral continuity of individual sandstone beds and type of facies and facies tracts in outcrops and subsurface. Moreover, each turbidite outer-fan lobe system must be studied individually, be- cause exceptional possible correlation exist between them, even contiguous.

\section{FACIES ASSOCIATION AND STRATIGRAPHIC STACKING}

The prograding stratigraphic Megasequences from Paleocene up to Lower Eocene, were deposited during several tectono-sedimentary and eustatic episodes; these ones are overlay by regional chronological upper bounding unconformity surfaces, and interpreted from variety of lithofacies (systems tracts), with diverse bedding geometry, textural and mineralogical composition, internal sedimentary structures and primary and secondary stratigraphic slumps. That is the reason why in this work was adopted the criteria proposed by Hubbard et al. (1985), as a tectonic mechanism for the subdivision fill into "Megasequences", driven by changes in tectonic and eustatic processes, based on chronostratigraphic units instead lithostratigraphic ones, as it is usually to the Chicontepec stratigraphic sequence.

The regional chronostratigraphic stacking from the foreland-basin, was established by Vasquez et al. (2014) in a detailed graphical Wheeler diagram with time intervals of $0.1 \mathrm{Ma}$, from the interpreted graphical biostratigraphic data, based on planktonic microforaminifera and nano-fossil assemblages in rocks from 33 wells. Such biostratigraphic sequences are bounded by five chronological upper regional unconformity surfaces (Ma), from Late Cretaceous / Early Paleocene up to Late Eocene: $65.5,60.4,54,46$ and $38.1 \mathrm{Ma}$, consecutively. 
These sequence boundaries fit to regional unconformity surfaces previously reported by PEMEX, as: K/T (Cretaceous/Tertiary boundary) and A, B and C unconformities, as the upper bounding surfaces of the overlay Paleocene and Lower Eocene members from the Chicontepec Formation.

The three Lower Paleogene Chicontepec sequences, underlie and overlie respectively, between the unconformities already reported by PEMEX and Vasquez et al. (2014), as: K/T, A, B, and C; which are interpreted, herein in this work, and previously by Aguayo, et al. (2013, 2016), as temporal prograding Megasequences; based on lithofacies of correlatable systems tracts assemblages and their settings, bounded by the regional upper chronological unconformity surfaces.

Unconformities K/T-A: Lower Megasequence (Lower Paleocene). Unconformities A-B: Middle Megasequence (Middle-Upper Paleocene). Unconformities B-C: Upper Megasequence (Lower Eocene) (Figures 5, 6).
1. Lower Megasequence: Lower Paleocene: 65.5-60.4 Ma (Danian). Sea-bottom shaley facies (Velazco Basal $\mathrm{Fm}$ ), and passive prograding and leveler outerfan with sandy-clayey facies, and clayey fringe frontal-splays (Lower Chicontepec).

2. Middle Megasequence: Middle-Upper Paleocene: 60.4-54 Ma (Selandian-Thanetian). Active prograding outer-fan lobe systems with sandy and silty facies (Middle-Chicontepec).

3. Upper Megasequence: Lower Eocene: 54-46 Ma (Ypresian-Lutetian). Slope instabilities and feeder channels: mass transport sediments and slumped fans (Upper Chicontepec).

The three major temporal prograding Megasequences bounded by the regional unconformity surfaces, and within them numerous local unconformity surface, are composite by the stacking of low-density turbidite systems tracts, which were deposited in bathyal marine

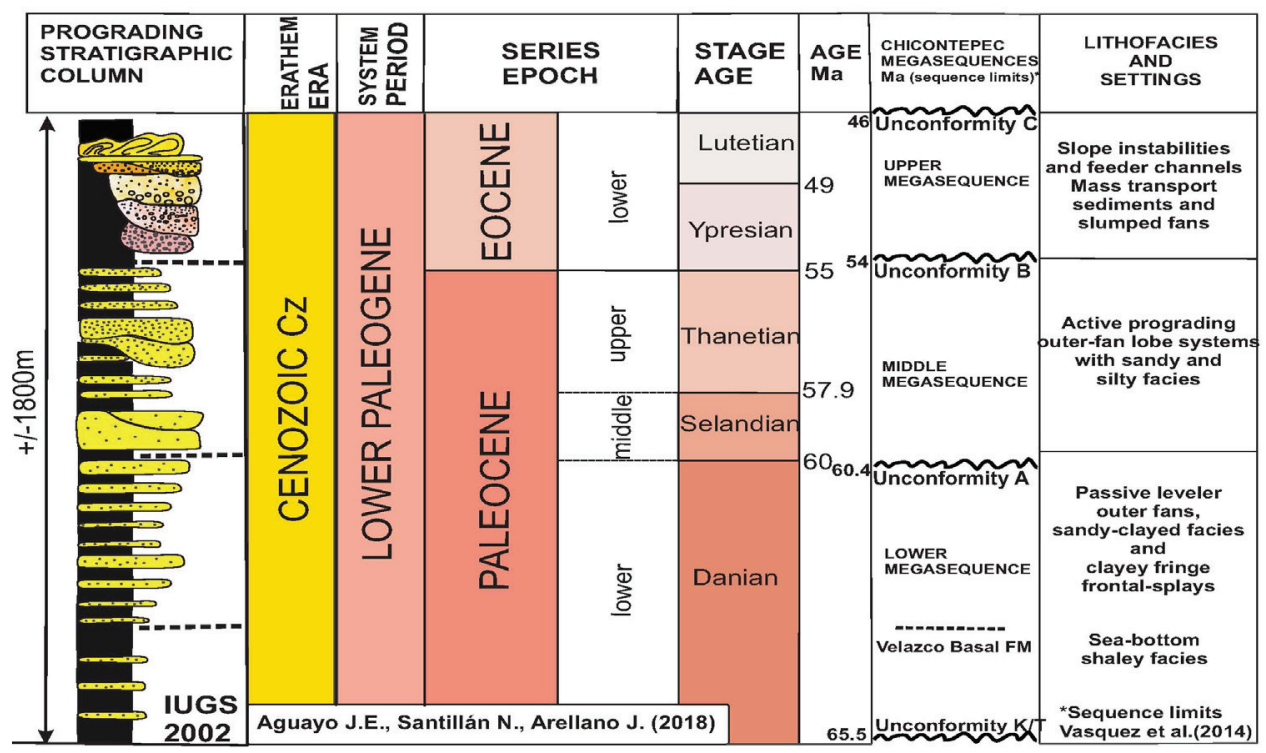

Figure 5. Temporal prograding Megasequences, sedimentary systems and settings (North-Central Sectors)

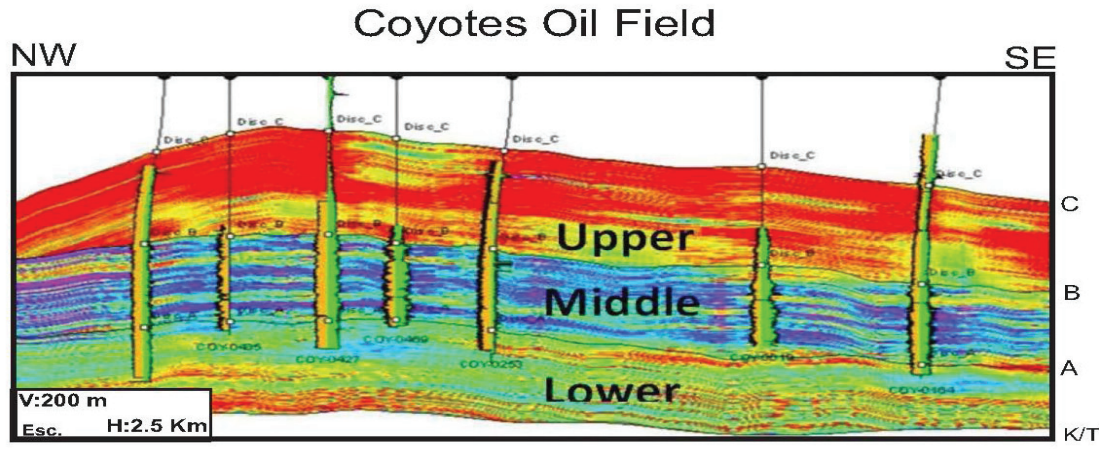

Figure 6. Seismic section and geophysical drilled-well logs to define the lithofacies from the three

Megasequences: Lower: shaley-clayey; Middle: sandy-silty; Upper: clayey $(\mathrm{CNH}-$ UNAM, 2012). 
environment, with more than $500 \mathrm{~m}$ depth; as it was interpreted by means of microforaminifera assemblages (Busch and Govela, 1978; Salazar,1980; Vasquez, et al., 2014), and from ichnofacies recognition (Bitter, 1983; Cossey, 2008); with more than $1800 \mathrm{~m}$ of thickness in the northwest and southwest borders of the basin (CNH-UNAM, 2012) (Figure 7). Such stratigraphic stacking overlie the sea-bottom facies, either one, the marly facies from the Upper Cretaceous Mendez Formation or the shaley facies with scarce thin-bedded fine-grained sandstone facies of the Velazco Basal Fm. (Lower Paleocene). The stratigraphic sequence pinch-out from southwest to northeast, and also from northwest to southeast (CNH-UNAM, 2012); whose record a series of genetically linked depositional and erosional events.

The thicknesses of the Chicontepec formations reported by Alzaga et al. (2008a), are supported by 4 drilled wells and seismic profiles laying out, along a stratigraphic section in subsurface oriented SW-NE, from the central sector of the foreland basin.

From SW to NE:
Upper Chicontepec Formation: 1814 to $474 \mathrm{~m}$ Middle Chicontepec Formation: 500 to $228 \mathrm{~m}$ Lower Chicontepec Formation: 550 to $150 \mathrm{~m}$

From subsurface of the Early Eocene mini-basin, the Megasequence thicknesses reported by CNH-UNAM (2012) were defined by drilled wells from 8 oil fields and seismic profiles, which were correlated along a stratigraphic section oriented NW-SE from Coyotes Oil field northern to Furbero Oil field southern (Figures 8, 9).

From NW to SE:

Upper Megasequence (Lower Eocene): 521 to 502 Middle Megasequence (Middle-Upper Paleocene): 481 to $219 \mathrm{~m}$

Lower Megasequence (Lower Paleocene): 513 to $55 \mathrm{~m}$
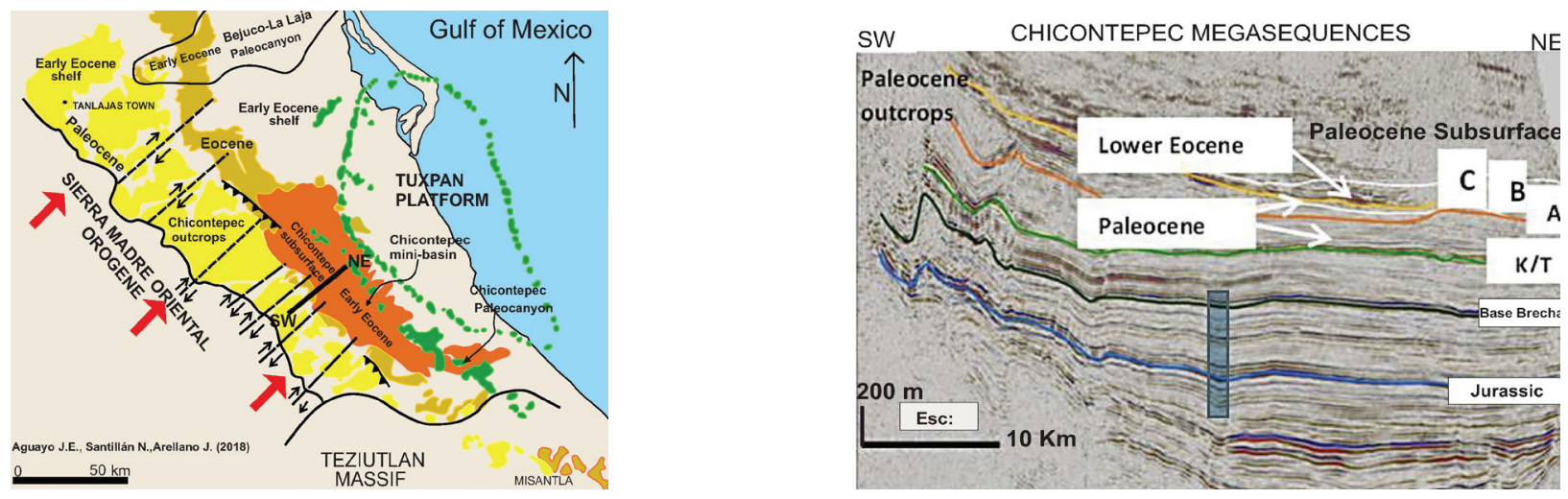

Figure 7. Chicontepec Basin in plan view and the SW-NE Seismic section at subsurface (CNH-UNAM, 2012)

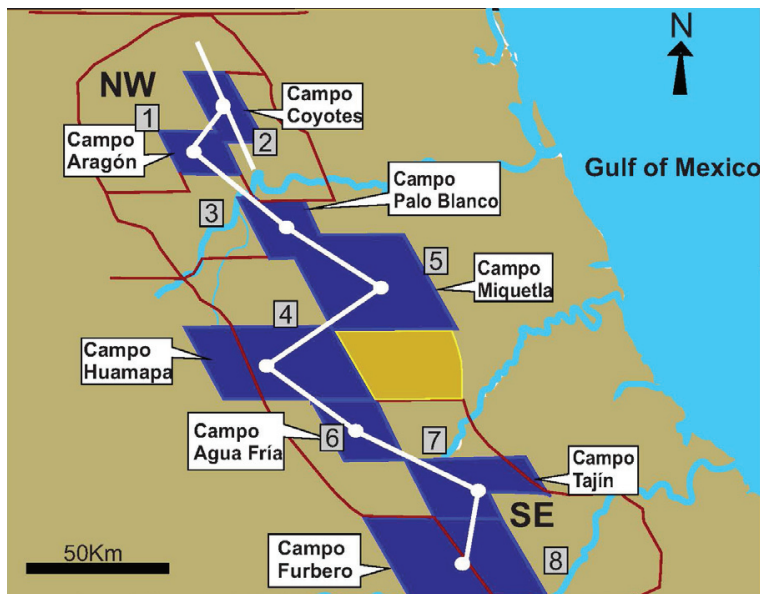

Figure 8. Chicontepec Oil Fields at the Chicontepec Basin (CNH-UNAM, 2012) 

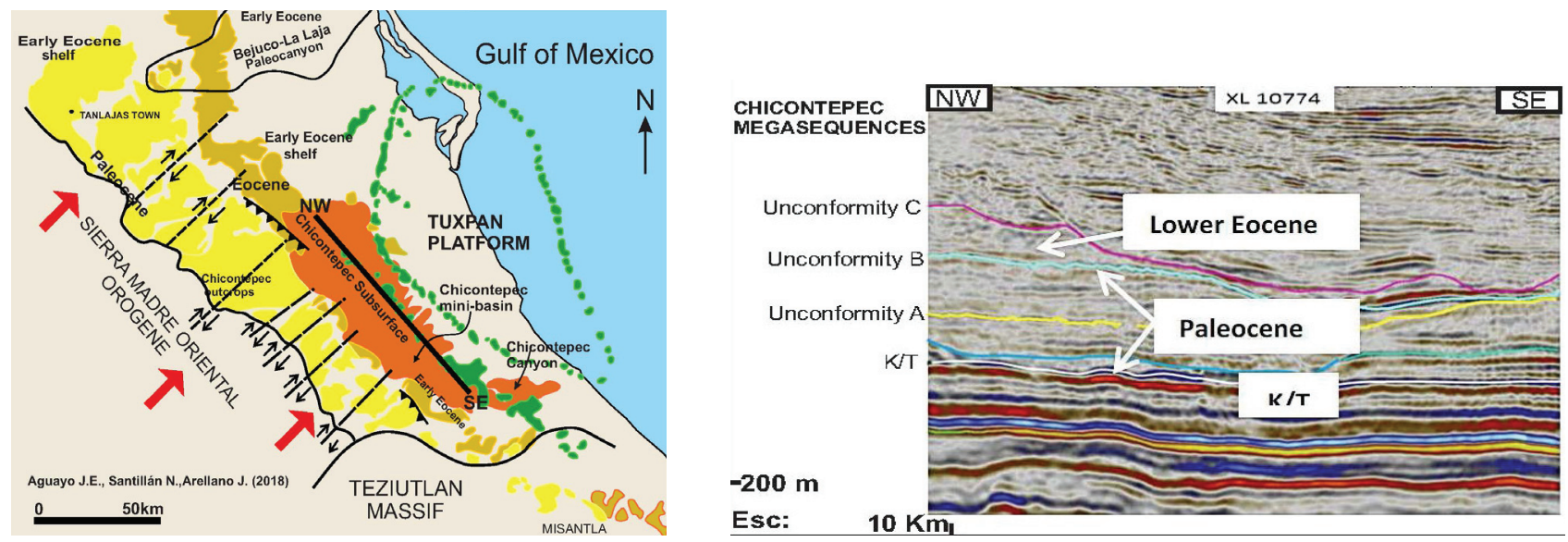

Figure 9. Chicontepec Basin in plan view and the NW-SE Seismic section in subsurface (CNH-UNAM, 2012)

\section{TECTONICS, DENSITY FLOWS AND OIL TRAPS}

The Sierra Madre Oriental emerged from Late Cretaceous up to Eocene, when the Mesozoic stratigraphic sequence, thrust-folded and faulted, by the northeastward compressive tectonic stresses from the Laramide Orogeny, against the Tuxpan-Island eastern. The Chicontepec Foreland Basin formed within that tectonic framework, by the loading pressure of the uplifted Sierra Madre Oriental Orogene, on the passive unfolded and thermally in subsidence Cretaceous basement; which was bended and tilted southwestward forming a prism, synchronously to the loading of the detached from the thrust-front syn-orogenic slumps northeastern, and with turbidity currents flowing southeastward, along the axial depocenter of the elongate basin and parallel to the toe-thrust front of the Sierra Madre Oriental Orogene, during Early Paleocene.

Since Middle up to Late Paleocene, the basement continued in subsiding, it was tilted to the southeast; the axial depocenter of the basin displaced progressively northeastern and synchronously to the turbidity flows southeastward; then spread laterally to the east and northeastern. During Early Eocene, a severe tectonic compressive pulses occurred, when the emerged Sierra Madre Oriental thrust-fronts displaced along the framed dextral SW-NE strike-slip fault system, and emplaced southward through time (Cossey, 2008). The western and northern margins of the basin emerged as shelves by tectonism and sea-level drop from eustatism, being shallower when the accommodation space filled by forced regressive stages (Rosenfeld and Pindell, 2004).

The basin eastern, reduced and became shorter, narrower and deeper by erosion (paleochannel), filled-up with massive chaotic and re-deposited slumps and muddy flow debris, resulting from the erosion of the mini-basin (paleochannel) margins and then, interbedded with deep-water turbidities which flowed southeastward, and also with coarse-grained sediments transported through the canyons along the western margin of the mini-basin; probably as consequence to the fit of the SW-NE strike-slip fault systems, as it was interpreted by Cossey (2008), and sketched in this work (Figure 10). On the other hand, the tectonic plateau of the Tuxpan Island tilted to the southeast, while at its southwestern border, the submarine canyon developed into the Early Eocene mini-basin; then, the canyon formed when the paleochannel was eroded deep enough through older Paleocene, Cretaceous, and Upper Jurassic stratigraphic sequences, nearby Poza Rica and Papantla towns at Veracruz State., and synchronously to the uplifting of the Teziutlán Massif (Busch and Govela, 1978).

During Late Eocene, the western Paleocene margin of the Chicontepec Basin was exhumed and eroded, the clastic erosional products are the coarse-grained lithofacies from the Tantoyuca Formation, as "molasse" facies (Benavides, 1956) or the "wild flysch" facies (Alzaga et al., 2008a), suggesting the end of the Laramide Orogeny.

Since Oligocene up to Neogene, the Tuxpan fore-bulge was bypassed by the clastic terrigenous sediments, when it was drowned during its sinking and tilting to the southeast and after the laramide stresses; the buried onshore Chicontepec Foreland Basin was subjected to NWSE dextral transpressive strike-slip fault systems (Figure 11). Resulting from the tectonic shear-stresses caused by the loading pressure to the northeast of the whole Paleocene-Eocene stratigraphic stacking against the western margin of the Tuxpan fore-bulge eastern, as consequence to the southeastward tilting of the underlie 


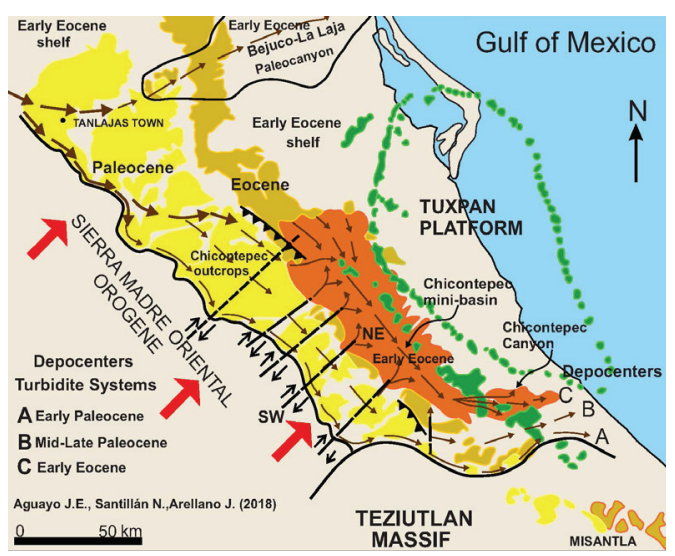

Figure 10. Depocenters of turbidity systems during Early Paleogene, and the SW-NE dextral strike-slip fault systems during laramide stresses

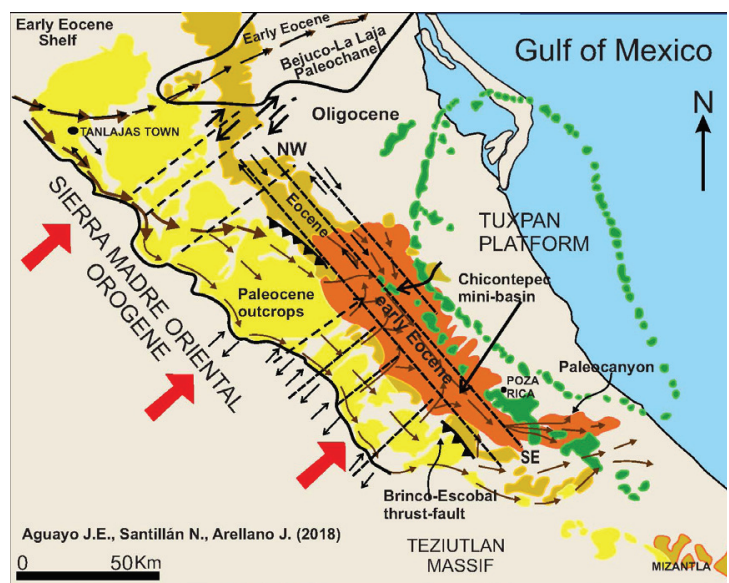

Figure 11. NW-SE dextral transpressive strike-slip fault systems after laramide stresses

passive and unfolded Cretaceous basement, and in accordance to the listric fault system occurring along the offshore continental slope, at the eastern margin of the Tuxpan fore-bulge (Alzaga et al., 2008b).

The NW-SE structural faulting system, and the highly fractured discontinue sandy lenses from the outer-fan lobe facies, are strongly related to the hydrocarbon migration, as conduits and traps, respectively (CNH-UNAM, 2012; Arellano, et al., 2013). The outerfan lobe facies are the most important oil reservoirs into the stratigraphic stacking of the Chicontepec Foreland Basin. The hydrocarbons from the underlay Cretaceous and Upper Jurassic rock sources, migrating almost vertically along the NW-SE dextral transpressive strikeslip faults, then spread laterally within the microfractured sandy lenses, and into the local and regional unconformable interbedded-erosive bounding surfaces, at different levels of the Chicontepec stratigra-

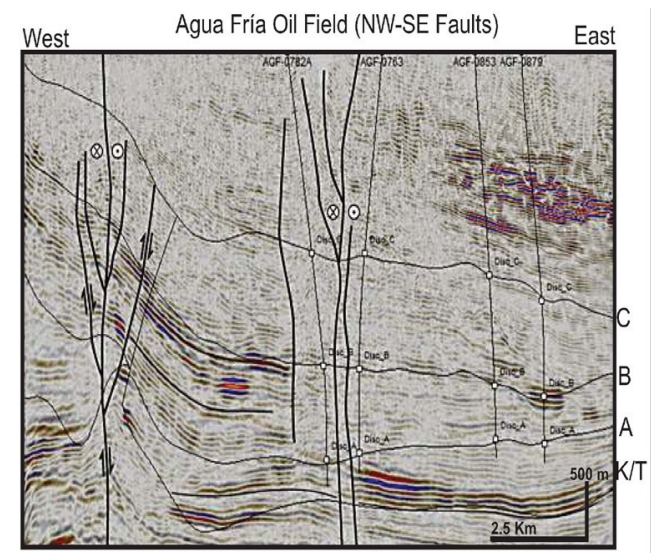

Figure 12. Seismic section. NW-SE dextral transpressive strike-slip fault systems as conduits for oil migration $(\mathrm{CNH}-$ UNAM, 2012)

phic column and above, mainly within the Middle Megasequence from Middle to Upper Paleocene, which is bounded by the unconformity erosional surfaces A-B , within it occurred the most active prograding sandy outer-fan lobe systems, as a hybrid petroleum system, as unconventional reservoirs with low permeability $(<0.01 \mathrm{Md})$ (Arellano et al., 2013) (Figure 12).

\section{Conclusions}

The Lower Paleogene Chicontepec Foreland Basin was a semi-restricted marine basin, at the southern region of the Tertiary Tampico-Misantla Basin or Tampico Embayment, onshore East-Central Mexico.

The Chicontepec Basin consists of syn-orogenic clastic sediments transported as low density turbidity systems in a deep marine bathyal environment, with more than $500 \mathrm{~m}$ depth. Such interpretation is supported by microforaminifera assemblages and ichno-facies analysis previously described by Busch and Govela (1978), Salazar (1980), Bitter (1983, 1993), Cossey (2008), Vasquez et al. (2014), among others.

In this work was adopted the criteria proposed by Hubbard et al. (1985), as a tectonic mechanism for the subdivision fill into "Megasequences" for the Chicontepec stratigraphic stacking; it driven by changes in tectono-sedimentary and also eustatic events, based on chronostratigraphic units instead lithostratigraphic formations.

The chronological upper regional unconformity regional surfaces from the three major Megasequences of the Chicontepec Basin with more than 1800 m thick, were previously reported by PEMEX and Salazar et al. (2014). Based on such chronological limits, herein in this work, were characterized and interpreted the three tem- 
poral prograding Megasequences, taken their most conspicuous assemblages of sedimentary systems (systems tracts) within numerous local unconformities, and pinched-out toward the margins of the basin. The stratigraphic Megasequences overlie the Early Paleocene sea floor with the marly facies of the Late Cretaceous Mendez Shale or the shaley and very fine-grained sandstone facies from the Early Paleocene Velazco Basal Fm.

The prograding Megasequences consist of outer-fan lobe systems, as thick and laterally extensive sandstones from non-channelized and detached outer-fan lobe facies. Each outer-fan lobe system seems to be unique, in terms of lateral continuity from the individual sandstone beds and type of facies and facies-tracts, bearing numerous local unconformities in outcrops and subsurface; therefore, each sedimentary system must be studied individually because exceptional possible correlation exist between them, even contiguous.

Two major tectonic and regional faulting systems were recognized at the Chicontepec Foreland Basin: the SW-NE dextral strike-slip fault systems, framing the easternmost tectonic steps of the emerged zones in the thrust-front of the Sierra Madre Oriental Orogene, during the laramide stresses; and the NW-SE dextral transpressive fault systems, with shear stresses and fracture systems, after laramide stresses. The latter fault systems were the vertical oil routes to the sandy microfractured oil traps, from the active prograding outer-fan lobe systems; being more abundant at the Middle Megasequence from Middle-Upper Paleocene, in a hybrid petroleum system, and as unconventional reservoirs with low permeability.

\section{RefERENCES}

Aguayo, C.J.E., Sandoval, O.J.H., Araujo, M.J., Santillán, P.N. (2006). Geología regional de la Cuenca de Chicontepec del centro-oriente de México, como antecedente para el estudio de su porción nor-occidental en afloramientos. III Simposio: La investigación y desarrollo en la Facultad de Ingeniería, UNAM (Conferencia y Resumen).

Aguayo, C.J.E., Arellano, J., Santillán, P.N., Meneses, L.L. (2013). Contribution to the improvement of the sedimentological model for the Chicontepec Paleochannel, Mexico. Heavy Oil: Latin America Conference and Exhibition, 1-6.

Aguayo, C.J.E., Santillán, P.N., Arellano, J.L. (2016). Sistemas sinorogénicos progradacionales y migración de HC'S en la Cuenca de Antepaís de Chicontepec del Paléogeno Inferior, Centro-Oriente de México. Seminario de Investigación y Docencia. Facultad de Ingeniería, UNAM, (Conferencia y Resumen).

Alzaga, H., López, M., Roure, F., Séranne, M. (2008). Interactions between the Laramide Foreland and the passive margin of the
Gulf of Mexico: Tectonics and sedimentation in the Golden Lane area, Veracruz State, Mexico. Marine and Petroleum Geology XXX, 1-23.

Alzaga, H., Granjeon, D., López, M., Seranne, M., Roure, F. (2008). Gravitational collapse and Neogene sediment transfer across the western margin of the Gulf of Mexico: Insights from numerical models. Tectonophysics XXX, 1-21.

Araujo, J. (2010). Análisis petrográfico y paragénesis diagenética en más de 90 muestras de núcleos seleccionados de pozos de los sectores norte y central del paleocanal de Chicontepec, procesados con Microscopio Electrónico de Barrido con dispersión de rayos-X. Subdirección de Ingeniería de Yacimientos del Instituto Mexicano del Petróleo, Reporte Técnico Interno, 1-60 (unpuplished).

Arellano, J., Meneses, L.L., Pérez, G.A., Rangel, G.E.E. (2013). Changing the geological paradigm of Mexico's largest hydrocarbon deposit: A stratigraphic and structural vision. Heavy Oil: Latin America Conference and Exhibition, 1-6

Ávalos, H. (2013). Determinación y comparación a escala de secuencias sedimentarias en yacimientos tight y sus implicaciones en la evaluación petrofísica, área central, Paleocanal de Chicontepec (tesis de Maestría en Ingeniería). Facultad de Ingeniería, UNAM, 170 pp. (unpublished).

Ávalos, H., Aguayo, J.E., Aquino, A., Méndez de León, J. (2017). Análisis petrofísico en yacimientos compactos; porción central del paleocañón de Chicontepec. Ingeniería Petrolera, 57(4), 238-260.

Benavides, L. (1956). Notas sobre la geología petrolera de México. Symposium on Accumulations of Oil and Gas. 20th International Geological Congress, 3, pp. 351-352.

Bitter, M.R. (1983). Sedimentology and Petrology of the Chicontepec Formation. Tampico Misantla Basin, Eastern Mexico (Thesis Master of Science). B.S. University of Kansas, Geology, 147 (unpublished).

Bitter, M.R. (1993). Sedimentation and Provenance of the Chicontepec Sandstones with Implications from Uplift of the Sierra Madre Oriental and Teziutlán Massif, East-Central Mexico. In: Pindell J.L. y Perkins R.F. (eds.). Mesozoic and Early Cenozoic Development of the Gulf of Mexico and Caribbean Region: A context for Hydrocarbon Exploration. Transactions, 13th Annual Gulf Coast Section of Society for Sedimentary Geology (GCSSEPM). Research Conference, 155-172.

Bouma, A.H. (1962). Sedimentology of some Flysch deposits: A graphic approach to facies interpretation. Elsevier Publ., $168 \mathrm{p}$.

Busch, D.A., Govela, A.S. (1978). Stratigraphy and Structure of Chicontepec Turbidites, Southern Tampico-Misantla Basin, Mexico. The American Association of Petroleum Geologists Bulletin, 62 (2): 235-246.

CNH-UNAM.(2012). Apoyo técnico especializado para el modelo geológico, estructural, sedimentario y de yacimientos de los campos del Paleocanal de Chicontepec. Reporte Técnico de la Facultad de Ingeniería, UNAM, (unpublished). 
Cossey S. (2018). Depositional history and sedimentology of the Paleocene and Eocene Chicontepec Formation, Mexico. GYMSA Report: 1-15, (unpublished).

Contreras, A. y Argáez, R. (1985). Consideraciones paleobiólogicas de los ichnofósiles de La Formación Chicontepec en el estado de Puebla. Revista del Instituto de Geología, 6 (I): 73-85.

Folk, R.L. (1974). Petrology of Sedimentary Rocks. Hemphill, Austin, Tex., $182 \mathrm{p}$.

Hubbard, R.J., Pape, J., Roberts, D.G. (1985). Depositional sequence mapping as a technique to establish tectonic and stratigraphic framework an evaluate hydrocarbon potential on a passive continental margin. In: Seismic Stratigraphy II (ed. by Berg O.R. and Woolverton D.). Memoir of the American Association Petroleum Geologists. Tulsa, 39, 79-91

López, E. (1979). Geología de México. Tomo II. 2da.edición. México, D.F., 454 p.

Mutti E. (1992). Turbidite Sandstones. Istituto di Geologia. Universitá di Parma (ed). 108 p.

Mutti, E. y Ricci, F. (1972). Le Torbiditi dell' Appennine Settentrionale: Introduzione all' Analisi di Facies. Memorie Societa Geologica italiana, 11, 161-199 (traducido al inglés por Nilsen T. H., 1978). International Geology Review, 20(2): 125-166.

Nájera, H. (1952). Estudio de las formaciones del Eoceno en la región de Poza-Rica. Boletín de la Asociación Mexicana de Geólogos Petroleros, 4(3-4): 71-115.

Ricci, F. (1975). Depositional Cycles in Two Turbidite Formations of Northern Apennines (Italy). Journal Sedimentary Petrology, 45:3-43.

Rosenfeld, J.H. y Pindell, J. (2004). Early Paleogene isolation of the Gulf of Mexico from the World's Oceans. AAPG. International Meeting, Cancun (Abstract with Program), p. 68.
Salazar, T. (1980). Chicontepec, 17640 millones de barriles. Petróleo Internacional, 37, 11, 40-58.

Santillán, P.N. (2009). Paleoambientes sedimentarios en facies turbidíticas en la Cuenca Terciaria de Chicontepec, Centro-Oriente de México (Tesis Maestría en Ciencias). Universidad Nacional Autónoma de México. 38 pp. (unpublished).

Santillán, P.N. y Aguayo, C.J.E. (2011). Facies sedimentarias turbidíticas del Terciario Inferior en la Cuenca de Chicontepec, Centro-Oriente de México. Ingeniería, Investigación y Tecnología, Universidad Nacional Autónoma de México.(Publ), 12(3), 337-352.

Sessarego, H.L., Robles, H.F., Sánchez, R.M. (2007). Field Trip for the Lower Tertiary Chicontepec Basin, Onshore Mexico: Facies and Depositional Environments. Schlumberger. Internal Report, p. 1-44, (unpublished)

Servicio Geológico Mexicano-B- (SGM). (2007). Léxico estratigráfico de México [on-line]. Disponible en: http://www.coremisgm.gob.mx/inicio.html

Sutter, M. (1984). Cordilleran Deformation along the Eastern Edge of the Valles-San Luis Potosí Carbonate Platform, Sierrra Madre Oriental Fold-Thrust Belt, East-Central México, Geological Society America. Bulletin, 95, p. 1387-1397.

Vasquez, R., Cossey, S., Nieuwenhuise, D., van, Davis, J., Castagna, J., Morales, M., Rámos, I. (2014). New insights into the Stratigraphic Framerwork and Depositional History of the Paleocene and Eocene Chicontepec Formation, Onshore Eastern Mexico. Search and Discovery Article \# 30334 (2014). AAPG. Annual Convention, Houston Tx. (Abstract with Programs). 